\title{
PURPOSE OF ASSOCIATION OF ENTERPRISES IN COOPERATIVES IN ZAPORIZHZHIA REGION
}

\author{
Lynenko A.V. \\ Zaporizhzhia National University \\ Ukraine, 69600, Zaporizhzhia, Zhukovsky str., 66
}

konf.econom.znu@gmail.com

\author{
ORCID 0000-0001-6473-6074
}

\section{Key words:}

economic efficiency, Zaporizhzhia region, cooperative, cooperation, business integration, development of the region, synergy.
In the article, it has been proven that small and medium-sized enterprises should cooperate to ensure their competitive advantages. However, according to the peculiarities of regional development, cooperatives are more likely to integrate businesses in one or more related industries within the region. Therefore, cooperation should be based on the principles of combining sectored and territorial integration. Statistical analysis of the dynamics of the number of different cooperatives in Ukraine and their comparison with the total quantity of legal entities are business entities showed the underdevelopment of cooperation between enterprises in Ukraine. Instead, a comparative analysis of the foreign practice of merging enterprises into cooperatives proves the economic effectiveness of such cooperation, as well as the positive impact of the activation of the cooperative movement on the development of regions. Research on the development of cooperatives in the Zaporizhzhia region shows the dominance of service cooperatives, which facilitate more effective cooperation of their participants. Thus, these arguments have provided the basis for substantiating the proposals for the development of cooperatives by creating appropriate associations of enterprises in order to increase the economic efficiency of their activities and strengthen the economic potential of Ukrainian regions. The results of horizontal and vertical analysis of statistics on the number of cooperatives in Ukraine became the basis for logical conclusions about the trends of development of domestic cooperatives, and their synthesis made it possible to identify the problematic and priority spheres of association of enterprises in cooperatives to ensure the economic development of regions. The monographic research method has been used to study the successful experience of operating the Mondragon Cooperative Corporation in Spain, as well as its development already internationally. The comparative analysis has made it possible to explore the foreign practice of merging enterprises into cooperatives in order to substantiate proposals for the activation of cooperatives in Ukraine by creating such associations of enterprises and providing for this economic development of the regions. A comparative analysis of the development of cooperatives in the Zaporizhzhia region with the tendencies of their functioning in Ukraine has revealed differences that point to the peculiarities of this region. It is advisable for companies that join a cooperative to achieve the synergy effect to consolidate participants within the Zaporizhzhia region, gradually expanding their activities.

\section{ДОЦІЛЬНІСТЬ ОБ'ЄДНАННЯ ПІДПРИЕМСТВ У КООПЕРАТИВИ В ЗАПОРІЗЬКОМУ РЕГІОНІ}

\author{
Линенко А.В. \\ Запорізький національний університет \\ Україна, 69600, м. Запоріжжя, вул. Жуковського, 66
}

\author{
Ключові слова: \\ економічна ефективність, Запорізький \\ регіон, кооператив, кооперація, \\ об'єднання підприємств, розвиток \\ регіону, синергія.
}

У статті доведено, що підприємства малого та середнього бізнесу для забезпечення своїх конкурентних переваг мають кооперуватися. Проте кооперативам, зважаючи на особливості регіонального розвитку, доцільніше об'єднувати підприємства однієї чи декількох суміжних галузей саме в межах регіону. Тобто кооперація має відбуватися на принципах поєднання галузевої та територіальної інтеграції. Статистичний аналіз динаміки кількості різних кооперативів в Україні та їх порівняння із загальною кількістю юридичних осіб - суб'єктів господарської діяльності засвідчили нерозвиненість кооперації між підприємствами в Україні. Натомість компаративний аналіз зарубіжної практики об'єднання підприємств у кооперативи доводить економічну ефективність такої співпраці, а також позитивний вплив активізації кооперативного руху на розвиток регіонів. Дослідження тенденцій розвитку кооперативів у Запорізькому регіоні 
засвідчує домінування обслуговуючих кооперативів, які сприяють більш ефективній співпраці їхніх учасників. Отже, зазначені аргументи дали підстави для обгрунтування пропозицій із розвитку кооперативів шляхом створення відповідних об'єднань підприємств задля підвищення економічної ефективності їхньої діяльності та зміцнення економічного потенціалу регіонів України. Результати горизонтального та вертикального аналізу статистичних даних щодо кількості кооперативів в Україні стали інформаційним підгрунтям для логічних висновків про тенденції розвитку вітчизняної кооперації, а їх синтез дав можливість визначити проблемні та пріоритетні сфери об'єднання підприємств у кооперативи для забезпечення економічного розвитку регіонів. Монографічний метод дослідження застосовувався для вивчення успішного досвіду функціонування Мондрагонської кооперативної корпорації в Іспанії, а також її розвитку вже на міжнародному рівні. Компаративний аналіз дав змогу дослідити зарубіжну практику об'єднання підприємств у кооперативи для обгрунтування пропозицій щодо активізації кооперації в Україні шляхом створення таких об'єднань підприємств і забезпечення за рахунок цього економічного розвитку регіонів. Порівняльний аналіз розвитку кооперативів у Запорізькому регіоні з тенденціями їх функціонування в Україні виявив відмінності, що вказують на особливості цього регіону. Підприємствам, які об'єднуються в кооператив для досягнення ефекту синергії, доцільно консолідувати учасників у межах Запорізького регіону, поступово розширюючи свою діяльність.

\section{Statement of the problem}

Until recently, economic development was secured almost solely by competition between individual economic entities. Of course, gaining a competitive advantage is a significant factor in economic efficiency. However, competitive wars or confrontations have both positive effects on the winners and a number of negative effects. But the world is changing, making business owners aware that working together and working together on a mutual benefit basis can produce better results than competition. In addition, cooperation does not directly deny competitiveness in business, but it makes this competition more civilized.

There are ongoing processes of consolidation, consolidation, integration of various areas of economic activity. For example, every third bank in Ukraine is a part of a banking group. In the real economy, both traditional business associations such as corporations or consortia, as well as new business associations such as clusters, strategic alliances, etc. are being created.

In the world, the development of economic relations is based on the principles of a combination of specialization and cooperation, which provides the effect of synergy. In Ukraine, cooperatives have not been sufficiently developed today, although such mergers of enterprises, along with other forms of mutually beneficial business cooperation, can stimulate effective regional development and contribute to strengthening the economic potential of Ukrainian regions.

\section{Analysis of recent studies and publications}

Since the cooperative form of business association is attractive enough to all participants of this integration process, the cooperation has been thoroughly researched by many scientists. However, in Ukraine, researchers are mostly exploring the issues of cooperative development in agriculture, although such cooperation is appropriate for many sectors and spheres of the national economy.

Among the scientific papers that cover a wide range of topical issues of the development of cooperative organizations, it is worth mentioning the work of Anna Lashch, which systematizes the prerequisites for the emergence of cooperation and outlines its prospects.

Scientists Vladyslav Honcharenko and Alla Milka substantiated new theoretical and methodological approaches to determining the socio-economic efficiency of cooperative enterprises and national cooperative systems.

Oleh Hirman's article explores the categories of cooperation and partnership as tools for sustainable regional development in Ukraine. Regarding the alternative areas that open up new horizons for the creation of cooperatives in the form of cooperatives, the practical guide Roksolana Baiko explores the experience of Germany and Austria in the development of energy cooperatives.

\section{Objectives of the article}

The purpose of the study is to substantiate proposals for mergers of enterprises in cooperatives to ensure the economic development of the Zaporizhzhia region. The objectives of the study are: statistical analysis of the dynamics of the number of different forms of cooperatives in Ukraine and the Zaporizhzhia region; identification of problems and obstacles to the development of cooperation in various spheres of the national economy; to study the best foreign experience of merging enterprises into cooperatives and substantiating proposals for economic development of Ukrainian regions by creating associations of cooperative enterprises.

\section{The main material of the research}

The cooperative movement in Ukraine is not something new, so cooperatives have been created on our territory in the past and in the past centuries. However, nowadays the cooperative form of cooperation and business association is still underdeveloped when compared to foreign practice. In particular, Anna Lashch is of the opinion, noting that "public, charitable organizations and associations of cooperatives do not carry out sufficient educational 
activities among the population in sufficient numbers... there are no cooperative training centres" [6].

According to the Law of Ukraine "On Cooperation" a cooperative is a legal entity formed by individuals and/or legal entities that voluntarily united on the basis of membership to conduct joint economic and other activities in order to meet their economic, social and other needs on a self-governing basis. The purpose of cooperation is to meet the economic, social and other needs of members of cooperative organizations on the basis of a combination of their personal and collective interests, the separation of risks, costs and income between them, the development of their self-organization, self-management and self-control.

According to the tasks and nature of the activity, cooperatives are divided into the following types: production, service and consumer. According to the directions of activity, cooperatives can be agricultural, housing, gardening, garage, trade, purchasing, transport, educational, tourist, medical, etc. [7].

The analysis of the topic of scientific publications on the problems of development of cooperation in Ukraine shows that the majority of authors investigates the issue of cooperation in the agricultural sphere.

It may even be a false idea that in our country the vast majority of cooperatives are agricultural. However, official data of the State Statistics Service of Ukraine indicate other proportions of the distribution of cooperatives by types and directions of activity [5].

Table 1 - Horizontal analysis of the quantity of cooperatives in Ukraine

\begin{tabular}{|c|c|c|c|c|c|c|c|c|c|}
\hline \multirow{2}{*}{ Indicators } & \multicolumn{8}{|c|}{ As of February 1} & \multirow{2}{*}{$\begin{array}{l}2020 \text { y. to } \\
2013 \text { y., \% }\end{array}$} \\
\hline & 2013 & 2014 & 2015 & 2016 & 2017 & 2018 & 2019 & 2020 & \\
\hline $\begin{array}{l}\text { Production } \\
\text { cooperatives }\end{array}$ & 2496 & 2792 & 2331 & 2320 & 2307 & 2428 & 2221 & 2207 & 88,42 \\
\hline Serving cooperatives & 20550 & 20597 & 16689 & 17484 & 18176 & 21644 & 19084 & 19579 & 95,27 \\
\hline $\begin{array}{l}\text { Consumer } \\
\text { cooperatives }\end{array}$ & 781 & 810 & 728 & 730 & 748 & 861 & 752 & 768 & 98,34 \\
\hline $\begin{array}{l}\text { Agricultural } \\
\text { production } \\
\text { cooperatives }\end{array}$ & 1220 & 1198 & 1006 & 995 & 996 & 1094 & 1004 & 1005 & 82,38 \\
\hline $\begin{array}{l}\text { Agricultural service } \\
\text { cooperatives }\end{array}$ & 944 & 1042 & 902 & 949 & 1015 & 1169 & 1216 & 1269 & 134,43 \\
\hline Other cooperatives & 7610 & 7149 & 2788 & 3327 & 3218 & 3386 & 3281 & 3278 & 43,07 \\
\hline Total cooperatives & 33601 & 33588 & 24444 & 25805 & 26460 & 30582 & 27558 & 28106 & 83,65 \\
\hline $\begin{array}{l}\text { Total number of } \\
\text { legal entities }\end{array}$ & 1343890 & 1373632 & 1075808 & 1123786 & 1188598 & 1239299 & 1302530 & 1354069 & 100,76 \\
\hline $\begin{array}{l}\text { The share of } \\
\text { cooperatives, } \%\end{array}$ & 2,50 & 2,45 & 2,27 & 2,30 & 2,23 & 2,47 & 2,12 & 2,08 & $x$ \\
\hline
\end{tabular}

Source: calculated by the author according to the data [5]

Thus, the dynamic analysis conducted in Table 1 shows that for the whole period from 2013 to 2020 (data were analysed as of February 1) the lion's share of cooperatives were servicing. Production cooperatives prevailed over consumer cooperatives. In 2015, the total number of cooperatives decreased significantly due to Russian aggression in eastern Ukraine and annexation of Crimea. From 2013 to 2017, the share of cooperatives in the total number of legal entities decreased, in 2018 it increased quite sharply almost to the value of 2013, but as of February 1, 2020, it is the lowest for the whole analysed period (Fig. 1).

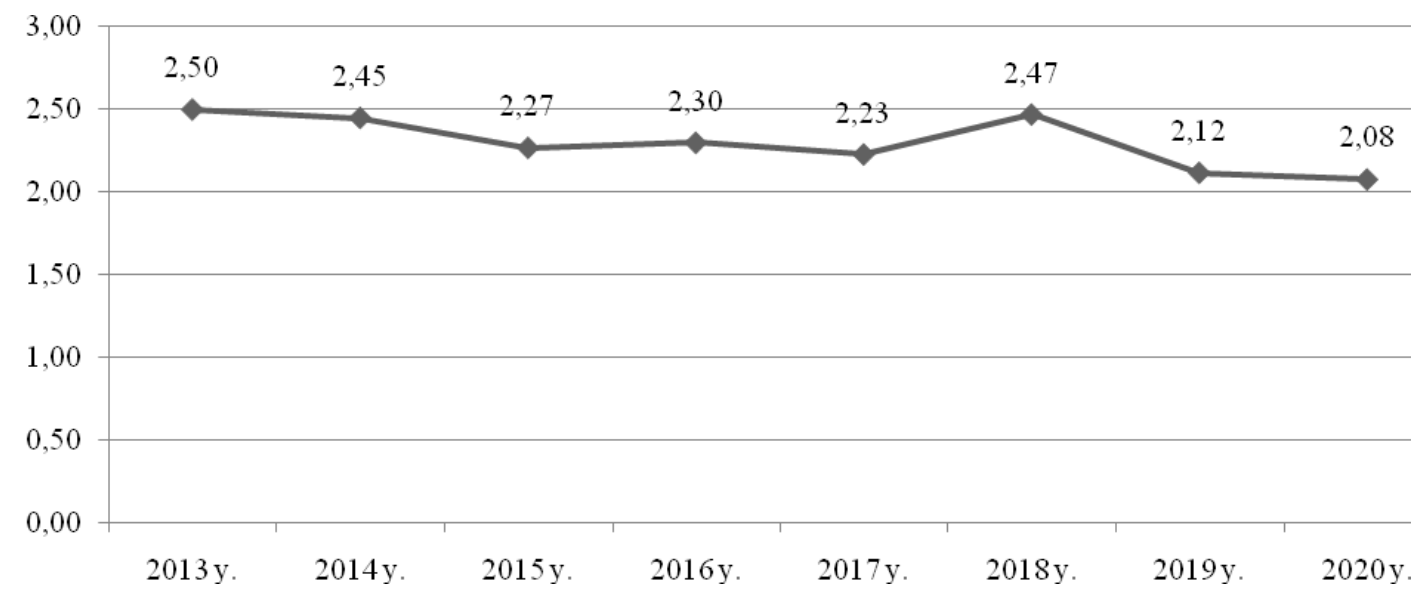

Fig. 1. Dynamics of the share of cooperatives in the total number of legal entities - economic entities, $\%$ 
An analysis of Table 2 shows that during the study period the share of production cooperatives increased slightly, as did the consumer cooperatives, while the share of service providers increased significantly against the backdrop of the share of other cooperatives.

Table 2 - Vertical analysis of the ratio of different forms of cooperatives

\begin{tabular}{|l|c|c|c|c|c|c|}
\multirow{2}{*}{\multicolumn{2}{c}{ Cooperatives }} & \multicolumn{2}{c|}{ As of February 1,2013 } & As of February 1, 2020 & \multicolumn{2}{c|}{2020 to 2013,+/- } \\
\cline { 2 - 8 } & quantity & $\%$ & quantity & $\%$ & quantity & $\%$ \\
\hline Production & 2496 & 7,43 & 2207 & 7,85 & -289 & 0,42 \\
\hline Serving & 20550 & 61,16 & 19579 & 69,66 & -971 & 8,50 \\
\hline Consumer & 781 & 2,32 & 768 & 2,73 & -13 & 0,41 \\
\hline Agricultural production & 1220 & 3,63 & 1005 & 3,58 & -215 & $-0,05$ \\
\hline Agricultural servicers & 944 & 2,81 & 1269 & 4,52 & 325 & 1,71 \\
\hline Others & 7610 & 22,65 & 3278 & 11,66 & -4332 & $-10,99$ \\
\hline Total & 33601 & 100,00 & 28106 & 100,00 & -5495 & $\times$ \\
\hline
\end{tabular}

Source: calculated by the author according to the data [5]

Table 3 provides a comparative analysis of the dynamics of the number of cooperatives in the Zaporizhzhia region, as well as their share in the total number in Ukraine by individual types and types of cooperative organizations.

The proportions and tendencies of the regional development of cooperatives are somewhat different from the national ones.

Table 3 - Comparative analysis of the number of cooperatives in Zaporizhzhia region to their number in Ukraine as a whole

\begin{tabular}{|c|c|c|c|c|c|c|}
\hline \multirow[b]{2}{*}{ Indicators } & \multicolumn{2}{|c|}{ To start with 2013} & \multicolumn{2}{|c|}{ To start with 2020} & \multicolumn{2}{|c|}{2020 to $2013,+/-$} \\
\hline & quantity & $\begin{array}{l}\text { share in total } \\
\text { in Ukraine, \% }\end{array}$ & quantity & $\begin{array}{l}\text { share in total } \\
\text { in Ukraine, \% }\end{array}$ & quantity & $\%$ \\
\hline Production cooperatives & 124 & 5,04 & 73 & 3,31 & -51 & $-1,73$ \\
\hline Serving cooperatives & 1186 & 5,75 & 1088 & 5,57 & -98 & $-0,18$ \\
\hline Consumer cooperatives & 3 & 0,39 & 3 & 0,39 & 0 & 0,00 \\
\hline $\begin{array}{l}\text { Agricultural production } \\
\text { cooperatives }\end{array}$ & 31 & 2,53 & 33 & 3,27 & 2 & 0,74 \\
\hline $\begin{array}{l}\text { Agricultural service } \\
\text { cooperatives }\end{array}$ & 16 & 1,69 & 25 & 1,97 & 9 & 0,28 \\
\hline Other cooperatives & 516 & 6,75 & 241 & 7,35 & -275 & 0,60 \\
\hline Total cooperatives & 1876 & 5,57 & 1463 & 5,21 & -413 & $-0,36$ \\
\hline $\begin{array}{l}\text { Total number of legal } \\
\text { entities }\end{array}$ & 49515 & 3,69 & 47441 & 3,51 & -2074 & $-0,18$ \\
\hline
\end{tabular}

Source: calculated by the author according to the data [5]

In Fig. 2, the tendency to decrease in the share of other cooperatives (trade, purchasing, transport, educational, etc.) and the increase of cooperative organizations are clearly observed in the Zaporizhzhia region.

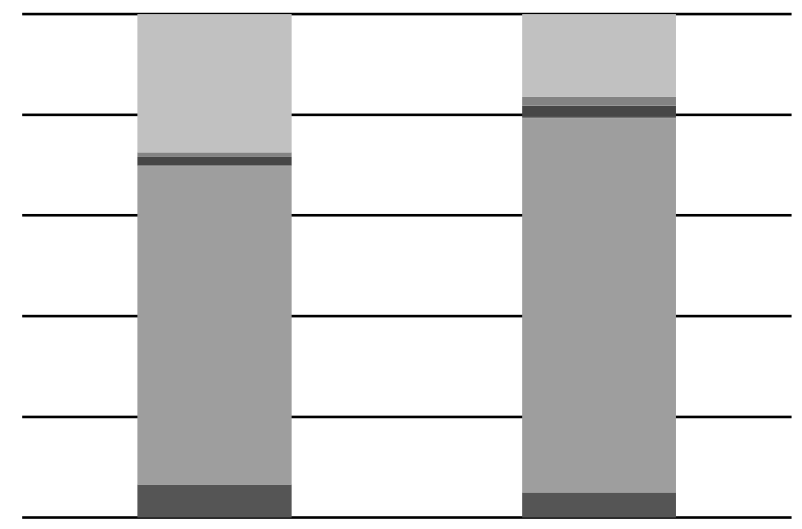

Other cooperatives

Agricultural service cooperatives

Agricultural production cooperatives

Consumer cooperatives

Serving cooperatives

Production cooperatives

Fig. 2. Structural changes in the number of different types and types of cooperatives in the Zaporizhzhia region 
Thus, in Ukraine and in the Zaporizhzhia region, there is a certain imbalance in the development of cooperatives in favour of the service providers, while other types are underdeveloped. Here is an example from the financial sector. Yes, the current banking law provides for the possibility of forming banks in the form of a cooperative, but now no such bank. In Europe, such banks have been in operation for a long time and have proven viable during the financial crisis, and the post-crisis period demonstrates their effectiveness.

With respect to the real economy, cooperative organizations and associations can be created in the industrial sector, in particular by consolidating mechanical engineering enterprises and other related industries.

In Spain, since 1956, the already powerful multi-industry Mondragon Cooperative Corporation has been developing, which not only ensures the economic development of the regions, but also stimulates the international economic relations of the country as a whole. Although now this large-scale cooperative already has many partners from different countries of the world, its participants are the enterprises of one municipality of Mondragon [2]. This fact proves that the territorial distribution of the cooperative members must have certain boundaries; as a rule, it may be a separate region.

In this context, Oleh Hirman rightly noted that the effectiveness of regional development management depends on the availability of effective organizational forms that are capable of contributing to the management tasks as much as possible. Such forms in the process of regional development in modern conditions are regional partnership and cooperation [3].

The economic growth of the regions depends on the balanced development of business entities, the merging of enterprises in cooperatives to increase efficiency through synergy.

\section{Conclusions}

Thus, cooperatives exist in Ukraine, but their share does not exceed $2.5 \%$ of the total number of economic entities. According to the positive changes in the economic development of the regions, which are associated with the revitalization of the cooperative movement, we have to say that there are not enough cooperatives. In addition, not only their number, but also the scope of the activity should be taken into account.

In addition, there are some disproportions when there are a lot of serving cooperatives and far fewer direct cooperatives. Successful foreign practice convincingly proves that the development of production cooperatives can stimulate the economic growth of the regions, so, in Ukraine, it is advisable to create an association of industrial enterprises in the form of cooperatives. This will increase their efficiency and strengthen the economic potential of the regions.

In the Zaporizhzhia region, it is advisable to develop agricultural cooperatives to enhance an agricultural potential. In addition, there are opportunities and suitable territories for the creation of energy cooperatives for the development of alternative energy (wind, sun, etc.), as well as production and service cooperatives that would unite small and small medium-sized enterprises of the machine-building industry, which are now trying to compete with large machine-building enterprises on their own.

\section{References}

1. Baiko, R. (2016). Enerhetychni kooperatyvy: dosvid Nimechchyny ta Avstrii [Energy cooperatives: the experience of Germany and Austria]. Kyiv: Financial and Economic Analysis Office in the VRU [in Ukrainian].

2. Centro Corporativo de MONDRAGON. (2020, February 25). mondragon-corporation.com. Retrieved from https://www.mondragon-corporation.com [in English].

3. Hirman, O.S. (2017). Kooperatsiia ta partnerstvo yak instrumenty staloho rehionalnoho rozvytku [Cooperation and partnership as tools for sustainable regional development]. Efektyvnist derzhavnoho upravlinnia - Efficiency of Public Administration, 3, 278-287 [in Ukrainian].

4. Honcharenko, V.V. \& Milka, A.I. (2016). Sotsialno-ekonomichna efektyvnist kooperatyvnykh pidpryyemstv ta natsionalnykh kooperatyvnykh system (novi teoretyko-metodolohichni pidkhody) [Socio-economic efficiency cooperative enterprises and the national cooperative systems (new theoretical and methodological approaches)]. Naukovyi visnyk Poltavskoho universytetu ekonomiky i torhivli - Scientific Bulletin of Poltava University of Economics and Trade, 2 (74), 9-17 [in Ukrainian].

5. Kilkist yurydychnykh osib za orhanizatsiino-pravovymy formamy hospodariuvannia [Quantity of legal entities by organizational and legal forms of management]. (2020, February 23). ukrstat.gov.ua. Retrieved from http://www.ukrstat.gov.ua [in Ukrainian].

6. Lashch, A.S. (2019). Kooperatsiia peredumovy vynyknennia i rozvytku [Cooperation: prerequisites for origin and development]. (2020, February 22). Efektyvna ekonomika - Efficient economy, 8. Retrieved from http://www.economy.nayka.com.ua/?op=1\&z=7231 [in Ukrainian].

7. Pro Kooperatsiiu [About cooperation]. (2020, February 24). zakon.rada.gov.ua. Retrieved from https://zakon.rada.gov.ua/laws/show/1087-15 [in Ukrainian]. 